\title{
Poems 4 Portugal / Poemas para Portugal
}

\section{HARLEM WALKING / 1995}

These are the streets

Of my childhood

The familiar

Allays changes

Traveling this underground

Railroad

Back and forward

At the same time

We look for safe houses

Rejuvenation of soul

Once daylight rises

To stalk our reflection

In mirrors upon lamp posts

These lips firm as freedom

We reclaim

We shall never not

Hear your slave ships

This is what you do

Not see:

We who are determined

Walk

With Oya and Oshun

When the loa of morning yawn

We have black magic

To brand the new day

These are only masks

We conceal what we let

You see 


\section{CAMINHANDO POR HARLEM/1995}

Estas são as ruas

Da minha infância

O familiar

Atenua as mudanças

A viajar por este subterrâneo

Trilho de comboio

Para trás e para a frente

Ao mesmo tempo

Procuramos casas seguras

Rejuvenescimento da alma

Assim que o dia nasce

Para perseguir o nosso reflexo

Em espelhos em postes de iluminação

Estes lábios firmes como a liberdade

Reclamamos

Nós nunca deixaremos nunca

De ouvir os vossos barcos negreiros

É isto que vós fazeis

Não ver:

Nós, os determinados

A caminhar

Com Oya e Oshun

Quando a loa da manhã boceja

Nós temos a magia negra

Para marcar o dia novo

Estas são apenas máscaras que

Nós escondemos o que vos deixamos

Ver

(c) 1995 Alexis De Veaux

Trad. Graça Capinha 


\section{FATHER I'VE}

1:

Father I've become

Obsessed

With your absence

So long ago thanksgiving

Claimed you its feast

I carved up memories

Lead with your right punch

With your left baby

Kill

Or be killed

Make sure your socks

Match pants match the shoes

Wear shades

Wear a hat

2:

He loved poetry

3:

Father

I am hungry

For something I cannot have

Like the child

In her daddies arm

At the supermarkets

I want to be

That face smeared with

Chocolate

And tears

Kissed away

I want to believe

The stubble of your shave

Is comfort to my cheeks

All the sweet I need 
4:

He was a shadow

Even in photographs

5:

Father I've become

You I

Imagine your moustache

On my lip

The pearl handled .32

Tucked at the neat

Of my back the way you

Swaggered

Down Harlem streets

A known criminal

Ready for danger

I am gunslinging poems

6:

Father

I've become what

You predicted

An outlaw life

Of my own

Words and ink

Stained crimes

Against the state

I've become the woman

And the man you wanted

Me to be 


\section{PAI EU}

1:

Pai fiquei

Obcecada

Com a tua ausência

Há tanto tempo o dia de acção de graças

Fez-te seu festim

Em que talhei recordações

Avança com o punho direito

Com a tua esquerda, querida

Mata

Ou deixa-te matar

Faz questão de as meias

Combinarem com as calças combinarem com os sapatos

Usa óculos escuros

Usa chapéu

2:

Ele adorava poesia.

3:

Pai

Tenho fome

De qualquer coisa que não posso ter

Como a criança

No braço dos seus papás

Nos supermercados

Quero ser

Aquela cara suja de

Chocolate

E lágrimas

Secas com beijos

Quero acreditar

Que o restolho da tua barba

É conforto para a minha face

Toda a doçura de que preciso 
4:

Ele era uma sombra

Mesmo nas fotografias

5:

Pai fiquei

Como tu eu

Imagino o teu bigode

No meu lábio

Uma calibre .32 pérola

No encaixe certo

Das minhas costas tal como tu

Exibida

Pelas ruas do Harlem

Criminosa conhecida

Pronta para o perigo

Pistoleira disparo poemas.

6.

Pai

Tornei-me no que

Tinhas previsto

Uma vida sem lei

A minha

Palavras e tinta

Crimes sujos

Contra o estado

Fiquei a mulher

$E$ o homem que querias

Que eu fosse

C1997 Alexis De Veaux

Trad. Graça Capinha 


\title{
VISITATIONS: Coimbra, Portugal
}

\author{
Make no mistake \\ The trade winds \\ You hear \\ Are the cacophonic \\ Conversations of slaves \\ Unfinished \\ With this life
}

Every map speaks

How close to my Africa

The teeth of your shores

Bite

Like ships at sea

Moaning towards

History

We are torn

As the rift between

Warring tongues

Time alone will not

Settle these different

Samenesses

I will not forget

Your grandiose churches

Your blessed catholic

Monuments

To conquistadors

The Museum Machado de Castro

Skinned by time

Dungeons

Beneath this courtyard

Of visiting poets

The corridors rank of stone I

Hyperventilate

Each step

To centuries ago 
My ancestors breathed

A subterranean fear

Where my skin screams

The visitations of spirits

Crowd your cobbled street

Visible as memory

The footprints Portuguese

And African

As undecipherable

As the meaning of chains

On legs and necks

Chattering

Bellowing

Begging

To go home

I cannot speak

This language

Tongue resists

A natural inclination

My poems

In English yes but

Who I am

Cannot

Be translated here

(C) 1997 Alexis De Veaux 


\section{VISITAÇÕES: Coimbra, Portugal}

Não se iludam

Os ventos alísios

Que ouvem

São as cacofónicas

Conversas dos escravos

Inacabadas

Nesta vida

Todos os mapas falam

De quão perto da minha África

Os dentes das vossas praias

Mordem

Como barcos no mar

Gemendo em direcção à

História

Nós estamos divididos

Como o fosso entre

Línguas em guerra

Só o tempo não chegará

Para resolver estas diferentes

Mesmidades

Eu não esquecerei

As vossas grandiosas igrejas

Os vossos abençoados e católicos

Monumentos

Aos conquistadores

O Museu Machado de Castro

Descascado pelas masmorras

Do tempo

Sob este átrio

De poetas em visita

Os corredores tresandam a pedra eu

Respiro mais depressa

Todos os passos

Para séculos atrás 
Os meus antepassados respiraram

Um medo subterrâneo

Onde a minha pele grita

As visitações dos espíritos

Enchem as vossas ruas empedradas

Visíveis como a memória

As pegadas Portuguesas

E Africanas

Tão indecifráveis

Como o significado das grilhetas

Nas pernas e pescoços

Rangendo

Gritando

Suplicando

Para voltar a casa

Eu não consigo falar

Esta língua

A que a língua resiste

Uma inclinação natural

Os meus poemas

Em inglês sim mas

Quem eu sou

Não pode

Ser traduzido aqui

(C) 1997 Alexis De Veaux

Trad. Graça Capinha

NOTA

* Alexis De Veaux é uma escritora negra feminista queer. Integra a conceituada lista de escritores americanos destacados pela LIT CITY, uma iniciativa de arte pública, desenvolvida em Buffalo, Nova lorque. Publicada em cinco línguas, a obra premiada da autora inclui títulos como Spirits In The Street (1973); Don't Explain, A Song of Billie Holiday (1980); Blue Heat: A Portfolio of Poems and Drawings (1985); e Spirit Talk (1997). É também autora de Warrior Poet, A Biography of Audre Lorde (2004), pela qual recebeu prémios prestigiados como o Gustavus Meyers Center for the Study of Bigotry and Human Rights Outstanding Book Award (2004). O seu romance Yabo (2014) foi distinguido pelo Lambda Literary Award for Lesbian Fiction 2015. 